\title{
Plasmodium vivax resistance to chloroquine (R2) and mefloquine (R3) in Brazilian Amazon region
}

\author{
Resistência do Plasmodium vivax pela cloroquina (R2) e \\ mefloquina (R3) na amazônia Brasileira
}

\author{
Maria das Graças C. Alecrim, Wilson Alecrim and Vanize Macêdo
}

\begin{abstract}
We report for the first time a patient with malaria due to Plasmodium vivax who showed $R 2$ resistance to chloroquine and $R 3$ resistance to mefloquine in the Brazilian Amazon region based on WHO clinical criteria for diagnosis of malaria resistance. Failure was observed with unsupervised oral chloroquine, chloroquine under rigorous supervision and mefloquine in the same scheme. Finally, the patient was cured with oral artesunate.
\end{abstract}

Key-words: Plasmodium vivax. Drug resistance. Chloroquine resistance. Mefloquine resistance.

Resumo Estamos relatando pela primeira vez um paciente com malária por Plasmodium vivax que mostrou resistência $R 2$ à cloroquina e resistência $R 3$ à mefloquina na Amazônia brasileira, de acordo com os critérios clínicos da OMS para resistência da malária. A falha foi observada com cloroquina oral, não supervisionada, cloroquina oral administrada sob rigorosa supervisão e com mefloquina no mesmo esquema. A paciente curou com o artesunato oral.

Palavras-chaves: Plasmodium vivax. Resistência a drogas. Resistência à cloroquina. Resistência à mefloquina.

We report for the first time $\mathrm{R} 2$ resistance to chloroquine and $\mathrm{R} 3$ resistance to mefloquine by $P$. vivax in the Brazilian Amazon region.

FSS, a 12 year-old female patient from Autazes Municipality in the State of Amazonas, Brazil, was diagnosed as having $P$. vivax malaria on July 14th 1997 (day 0) at the Instituto de Medicina Tropical do Amazonas, Manaus, Brazil. Day 0 parasitemia was 250 parasites $/ \mu$ l. The patient was treated with $10 \mathrm{mg} / \mathrm{kg}$ body weight oral chloroquine on the first day and $7.5 \mathrm{mg} / \mathrm{kg}$ on the second and third days. On day 4 parasitemia was $500 / \mu l$. On day 7 blood was negative. On day 9 parasitemia was $1,000 / \mu \mathrm{l}$ when we treated her with $20 \mathrm{mg} / \mathrm{kg}$ mefloquine. On day 19 parasitemia was $3,000 / \mu l$. She was treated again with the same chloroquine dosage in a directly observed schedule. On day 3 of the last scheme parasitemia was $3,100 / \mu l$.

On day 5 parasitemia decreased to $500 / \mu \mathrm{l}$ and increased to $800 / \mu$ l on day 7 , showing the R2 pattern of $P$. vivax chloroquine resistance.

The patient remained stable despite the level of parasitemia that increased to 1,720 on day 10. She was then treated with a supervised dose of $20 \mathrm{mg} / \mathrm{kg}$ mefloquine. Parasitemia decreased to $258 / \mu \mathrm{l}$ on day 3 and increased to $4,472 / \mu$ l on day 7 , showing the R3 pattern of $P$. vivax resistance

Instituto de Medicina Tropical do Amazonas. Universidade do Amazonas, Manaus, AM. Núcleo de Medicina Tropical e Nutrição/Universidade de Brasília, Brasília, DF.

Endereço para correspondência: Drª Maria das Graças C. Alerim. Avenida Pedro Teixeira s/no․ Dom Pedro I. $69040-000$ Manaus, AM. Tel: 5592 238-2801; Fax: 5592 238-7220.

Recebido para publicação em 2/10/98. 
to mefloquine. Because of therapeutic failure with chloroquine and mefloquine the patient was treated with oral $100 \mathrm{mg} /$ day artesunate, $50 \mathrm{mg}$ b.i.d. for five days. Parasitemia was negative on day 2. Primaquine treatment was started on day 3. The patient was followed up weekly until day 45 when she returned to Autazes Municipality.

$P$. vivax resistance to chloroquine was reported for the first time in 1989 by Schuurkamp et al in New Guinea9. Since then other authors confirmed it in the literature 1236 . In 1996, Phillips et al8 described for the first time $P$. vivax resistance in South America in a strain from Guyana.
In 1992 Garavelli and Corti4 reported a patient with $P$. vivax malaria resistant to chloroquine in Brazil. However, Loyola and Rodriguez analyzed this case and concluded that it was a relapse after primaquine treatment 5 .

We did not have any possibility to measure drug levels, but treatment was supervised and the patient did not have any gastrointestinal alteration which could impair drug absorption.

We conclude that the resistance patterns observed are compatible with a strain with R2 resistance to chloroquine and $\mathrm{R} 3$ resistance to mefloquine using the $\mathrm{WHO}$ classification of clinical resistance in malaria?.

\section{REFERENCES}

1. Baird JK, Basri H, Purnomo, Bangs MJ, Subianto B, Patchen LC, Hoffman LS. Resistance to chloroquine by Plasmodium vivax in Irian, Jaya, Indonesia. American Journal of Tropical Medicine and Hygiene 44:547-552, 1991.

2. Baird JK, Canete-Miguel E, Masbar S, Bustos DG, Abrenica JA, Layawen AVO, Calulut JM, Leksana B, Wignall FS. Survey of resistance to chloroquine by falciparum and vivax malaria in Palawan, The Philippines. Transactions of the Royal Society of Tropical Medicine and Hygiene 90:413-414, 1996.

3. Dua VK, Kar PK, Sharma VP. Chloroquine resistant Plasmodium vivax malaria. India. Tropical Medicine Health 61:816-819, 1996.

4. Garavelli PL, Corti E. Chloroquine resistance in Plasmodium vivax: The first case in Brazil. Transactions of the Royal Society Tropical Medicine and Hygiene 86:128, 1992.

5. Loyola EG, Rodriguez MH. Chloroquine resistant $P$. vivax in Brazil? Transactions of the Royal Society of Tropical Medicine and Hygiene 86:570-571, 1992.
6. Marlan-Than, Myat-Phone-Kyaw, Aye-Yu-Soe, KhaingKhaing-Gyi, Ma-Sabai, Myint-Oo. Development of resistance to chloroquine by $P$. vivax Myanmar. Transactions of the Society of Tropical Medicine and Hygiene 89:307308, 1995.

7. Organização Mundial de Saúde. Quimioterapia del paludismo y resistencia a los medicamentos antipalúdicos. Organización Mundial de la Salud. Serie de Reportaje Tecnico nำ 529, 1973.

8. Philips EJ, Keystone JS, Kain KC. Failure of combined chloroquine and high-dose primaquine therapy for $P$. vivax malaria acquired in Guyana, South America. Clinical Infectious Diseases 23:1171-1173, 1996.

9. Schuurkamp GJ, Spicer PE, Kereu RK, Bulungol PK. A mixed infection of vivax and falciparum malaria apparently resistant to 4-aminoquinoline: a case report. Transactions Royal of the Society Tropical Medicine and Hygiene 83:607-608, 1989. 